\title{
Shariah-compliant FinTech in the banking industry
}

\author{
Maria Todorof ${ }^{1}$
}

Published online: 5 April 2018

(C) ERA 2018

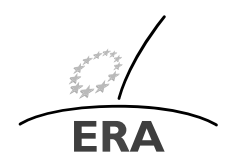

EUROPÄISCHE RECHTSAKADEMIE ACADEMY OF EUROPEAN LAW ACADEMIE DE DROIT EUROPEEN ACCADEMIA DI DIRITTO EUROPEO TRIER - TREVES - TREVIRI

\section{Introduction}

To address Shariah and FinTech in the same breath may sound counterintuitive. Still, this article will question whether non-secular Islamic banking could coexist with and benefit from the disruptiveness of FinTech. To this end, an argument will be put forward that Shariah-compliant finance can absorb some of the incarnations of FinTech without the latter contradicting Shariah principles. Furthermore, it will be suggested that some financial innovations such as peer-to-peer (P2P) lending may have profoundly beneficial effects on users in a way which is particularly relevant to Muslims.

In terms of structure, this paper will be divided in the following parts. Part One will briefly introduce the reader to the basics of Shariah finance law. This will be done by reference to Shariah's philosophical and religious underpinning. Part Two will compare the two types of banking. Part Three will look into what FinTech is and how it relates to modern banking, particularly conventional banking. Part Four will inform on the stage of implementation of FinTech in Islamic finance and will discuss Shariah-compliant P2P lending in more detail. Part Five will conclude that the introduction of FinTech in Islamic banking can increase its general competitiveness and inclusiveness by incorporating a greater number of products and services, lowering their existing price and closing the credit gap, existing in many Islamic countries.

\footnotetext{
M. Todorof

MTodorof@era.int

1 Trier, Germany
} 


\section{Part One}

\section{What is Shariah law and what is it about Islamic banking law which fascinates the most?}

\section{Overview}

Before elaborating on this, a warning is due that because this paper is concerned with how Shariah law operates in the sphere of financial services, most notably in banking, it can not examine in the necessary depth all aspects of Shariah. Instead, this author will try to map out Shariah's most fundamental elements, while focusing in more detail on what is expected from a financial transaction in order to comply with Shariah law.

In terms of how Shariah (the divine) law has come into existence and how it operates, it follows the Quran and the Sunna (which contain the teachings and practices of the holy prophet Mohammad) ${ }^{1}$ and it is brought to ordinary people by means of Islamic jurisprudence, known as Figh. ${ }^{2}$ Shariah not only contains the law of Islam, but is the law itself, the prescription and the proscription of various practices intended to preserve the moral integrity of the Muslim population. ${ }^{3}$ While there are many schools of Shariah, ${ }^{4}$ it is important to appreciate that Islam (and by extension Shariah as its practical manifestation) is not a religion where a broad interpretation of its founding principles is permitted. ${ }^{5}$ However, there is some evidence to suggest that, at least where financial transactions are concerned, this relative rigidness is applied mostly in relation to the results and not so much to the way they are reached. Furthermore, it appears that if a particular interpretation of a Shariah principle is likely to lead to a Shariah-compliant result, it would more readily be accepted by Shariah courts (should any such interpretation reach the stage where it has to be scrutinised by them). ${ }^{6}$ Relevantly to this paper, to the extent that there is some room for manoeuvre, this has been applied in the case of those FinTech based financial instruments, which have been deemed to be (with the help of a lot of legalistic exercises) Shariahcompliant.

\section{The most important Shariah principles}

These are generally uncontested by Muslims and are summarised below:

- The interest of the community takes precedence over the interests of the individual;

- Relieving hardship takes precedence over promoting benefit;

\footnotetext{
${ }^{1}$ Islamic Finance Advisory Board [27]. See also, Abou El Fadl [1].

${ }^{2}$ Fiqh is divided into jurisprudence covering the personal aspects of a Muslim's life (figh-ul-Ibadaat) and jurisprudence governing all social activities of Muslims, including financial dealings and transactions (figh-ul-muamulaat). This paper will be concerned with the latter. See, Islamic Finance Advisory Board [26].

${ }^{3}$ Abou El Fadl [1].

${ }^{4}$ Understanding Islam [40].

${ }^{5}$ But cf. Berger [7]. See also, Feridon [13].

${ }^{6}$ University of Pennsylvania [41], p. 2.
} 
- A bigger loss cannot be prescribed to alleviate a smaller loss and a bigger benefit takes precedence over a smaller one. Conversely a smaller harm can be prescribed to avoid a bigger harm and a smaller benefit can be dispensed with in preference to a bigger one. ${ }^{7}$

In the context of financial markets these principles work in the following way:

Interest of the community While they would happily promote an individual's financial interests, Islamic finance practitioners would always first consider how well these fit within the narrative of the common wellbeing. Common wellbeing in this context includes not only the financial stability of one's household but also the stability of the financial institution facilitating the transaction. This would mean that if a transaction contains too much risk (while remaining potentially capable of bringing benefit to those engaged), it will not be considered Shariah-compliant and it will not be carried out. Furthermore, a transaction can be considered to be against the interest of the community if it fails to meet some other Shariah principles-for example, if it relates to forbidden products or services. In such a case, the outcome would be the same, i.e., the transaction will not take place.

Relieving hardship Linked to the above, a Shariah-compliant banker is more likely to allow the funding of a transaction which would potentially alleviate one's poverty (including by taking a charitable action) than to finance a transaction for the sake of one's getting richer.

These two principles arguably contradict the much stronger focus on individualism which is characteristic of Western society, although admittedly, the latter has moved towards increased communality with the introduction of the welfare system in the second half of the twentieth century and the rise in consumer protection regulation in recent decades. Furthermore, in the West, accumulating and/or striving to accumulate personal wealth is considered a positive trait and more specifically, a trait proving one's capacity to act as a mature and accomplished human being. In distinction, Muslims are expected to look after resources, while remaining observant of the relevant Shariah law prohibitions. They are also encouraged to enjoy the fruits of their endeavours as long as they do not venture outside the confines of the Islamic moral code. ${ }^{8}$ This code is based on a pursuit of justice, fairness and social justice where the interest of the individual is balanced against the interests of society. Relevantly, it is expected that one should not pursue one's material goals in disregard to one's spiritual development; rather, the two aspects of life should be reconciled in a way guaranteeing that the person will not live in poverty, without at the same time indulging in materialism. ${ }^{9}$

Policy on loss and harm It is submitted that this principle encapsulates the general caution exercised by Shariah financial experts in financial matters and it is there to underpin Shariah policy on risk management and community values discussed in the first two principles.

\footnotetext{
${ }^{7}$ Institute of Islamic Banking and Insurance [18].

${ }^{8}$ Berger [7], p. 336.

${ }^{9}$ Jamaldeen [28].
} 


\section{Part Two}

\section{The two kinds of banking compared}

\section{Overview}

Despite the fact that Islam as a religion exists since the seventh century $\mathrm{CE},{ }^{10}$ Islamic banking has only relatively recently come into existence, notably, in the $60 \mathrm{~s}$ of the 20th century. ${ }^{11}$ By way of contrast, there are examples of proto-conventional banking going back as far as 2000 BC in Assyria and Sumeria. ${ }^{12}$ Since its inception, proto-conventional banking was based on the provision of loans, in addition to the safeguarding of deposits. Little by little, banking, which always included the lending of money (thus treating money as a commodity), gained popularity with the general population and became more and more widespread, not accounting for cultural and religious background. ${ }^{13}$ The usefulness of banking and banking principles was so undoubted and so uniformly accepted that it became possible, particularly from the Renaissance onwards, to eventually reconcile the ethical banking employed by the Catholic Church with the practices adopted by the Western lending institutions of the past centuries. ${ }^{14}$ Europe gradually became a place where financial institutions resembling modern banks started to appear. Despite some differences that such institutions may have exhibited in the way they operated, there were some common denominators in the model adopted by them. These common denominators were however in stark contrast to what would be permitted under Shariah law. It will be useful, therefore, to explain the Shariah-specific prohibitions in order to better understand how Shariahcompliant finance compares to its Western counterpart in general and in particular, how it compares in the sphere of banking and moneylending.

\section{Prohibitions under Shariah finance law}

The main Shariah prohibitions related to financial transactions are discussed below:

\section{(A) Interest $(r i b a)^{15}$}

Arguably the most important Shariah law prohibition, riba means a restriction on usury or even on loaning of money with some interest. ${ }^{16}$ While the approach to prohibition of interest has admittedly differed over the course of the last centuries (with

\footnotetext{
${ }^{10}$ McKeefery [34]. See also, Encyclopaedia Britannica [11].

${ }^{11}$ The first modern Islamic bank, Mit Ghamr Savings Bank in Egypt, was opened in 1963. See, Islamic Banker [24].

${ }^{12}$ History World [16].

${ }^{13}$ History World [16]. See also, Beattie [5].

${ }^{14}$ Thai Bank Museum [38].

${ }^{15}$ Visser [42], p. 38.

${ }^{16}$ Visser [42], p. 38. 
some scholars adopting a more permissive attitude towards riba than others), the current trend in Islamic finance is to regard all riba as non-permissible. ${ }^{17}$ This difference to Western banks is important.

As riba is interpreted to mean 'unjustifiable increase of capital', ${ }^{18}$ it can be argued that the reach of the prohibition could extend to cover a lot more than just interest on loans. For example, it is arguable that the prohibition of riba may render many instances of trading non-compliant with Shariah, because 'any guaranteed increase in return tied to the maturity and the amount of principal, regardless of the performance of the investment, would be considered riba and is strictly prohibited. ${ }^{19}$ As will be seen further below, FinTech penetrates or is used by a great number of financial services/banking activities and contexts, including, of course, trading. This suggests that perhaps FinTech will have very limited application in Islamic finance law. However, whether this is indeed the case, will be discussed in Part IV of this paper.

(B) Speculation/gambling (qimar $)^{20}$

Literally translated, al-qimar means betting and waging. It refers solely to games of chance where there are always two parties: a winner and a loser. ${ }^{21}$ This scenario can be easily translated to some of the riskiest conventional financial instruments (for example, futures), which due to their inherently speculative nature would be explicitly forbidden by Islamic finance law. ${ }^{22}$ It should be noted, however, that there are opinions indicating that derivative contracts such as forward and futures could be considered Shariah-compliant, regardless of their risky nature, if certain measures are taken to offset their riskiness. Such measures include the introduction in these contracts of terms and conditions, consistent with Shariah law. ${ }^{23}$

(C) Unearned income (maysir) ${ }^{24}$

Maysir is a broader term and encompasses gambling, including but not limited to games of chance. The reason why Shariah law prohibits maysir type of income is that it is a randomly generated, luck-based income rather than profit, accumulated through careful consideration of the transactional risks involved. ${ }^{25}$ Furthermore, maysir is prohibited not only as regard the financial outcome it produces but also as a matter of fact. What is unacceptable is that maysir operates on the basis of immoral inducement and on the basis of qimar: When engaging in maysir, the parties to the transaction hope that they will profit by chance (which is essentially gambling or speculation). ${ }^{26}$

\footnotetext{
${ }^{17}$ Haltom [15], p. 17.

${ }^{18}$ Institute of Islamic Banking and Insurance [18].

${ }^{19}$ Institute of Islamic Banking and Insurance [18].

${ }^{20}$ Islamic Finance Advisory Board [26].

${ }^{21}$ Investment \& Finance [19].

${ }^{22}$ Injadat [17].

${ }^{23}$ Injadat [17], p. 248-249.

${ }^{24}$ Islamic Finance Advisory Board [26].

${ }^{25}$ Investment \& Finance [19].

${ }^{26}$ Investment \& Finance [19].
} 
(D) Excessive risk/uncertainty/deceit ( gharar $)^{27}$

In terms of reconciling conventional with Islamic finance, gharar could arguably be an interesting prohibition because it is difficult to measure the degree of uncertainty of a specific risk or whether a particular risk can be qualified as 'excessive'. As with other prohibitions, their purpose is to ensure that the participants in a commercial transaction will not be deceived due to unclear contract terms or uncertain quality of the product subject to the transaction or the transaction itself. ${ }^{28}$ Nevertheless, it is suggested that this generality of gharar may potentially open the door for some disruptive new practices and products to take place in the Islamic financial market in general and Islamic banking market in particular.

(E) Trading in some products or industries ${ }^{29}$

Shariah law proscribes trading in products such as alcohol, pork (and all meat not slaughtered in accordance with Shariah law), tobacco, illegal drugs and illegal activities, weapons, particularly those that cause collateral damage and products of the entertainment industry (adult entertainment being the most obvious, although this prohibition also extends to erotic art, some types of non-Islamic music and films and gambling). ${ }^{30}$ The relevance of the above is that even if a FinTech product, which could in principle function under Shariah law, is identified, it will not be permitted under Islamic finance law if it is linked to (a derivative of) assets coming from prohibited industries or a prohibited product.

The difference with the Western way of banking is summarised in the below quote where it has been remarked that in conventional banking:

- the investor/lender is guaranteed a predetermined rate of interest or return;

- unrestricted profit maximisation [is sought-as] illustrated by derivatives trading;

- lending money and getting it back with compound interest is the fundamental function of the conventional banks. Money is both a commodity and the motivation;

- additional money (penalty and compounded interest) [can be charged in the] case of defaulters;

- often, lender/bank interest becoming forefront. [Conventional banking] makes no effort to ensure growth with equity;

- since income from advances/loans is fixed, little importance is given to developing expertise in project appraisal and evaluation;

- risks are transferable at a price (and sometimes incremental). ${ }^{31}$

It could be suggested therefore that the most key area where Islamic and conventional banks differ is that of how money is treated.

\footnotetext{
${ }^{27}$ Visser [42], p. 52.

${ }^{28}$ Investopedia [21].

${ }^{29}$ Such as weapons, alcohol and pornography.

${ }^{30}$ Jamaldeen [28].

${ }^{31}$ Bank Islam [4].
} 


\section{The issue of money}

As mentioned, the way money is treated appears essential for the division between conventional and Islamic banking. Understandably, the Shariah law prohibitions take place within a Shariah moral/philosophical context. In that context, all property, including money, is treated as belonging to God (Allah). Furthermore, unlike conventional banking, Shariah finance does not treat money as a commodity but as having time-value. While the principle of the time value of money is not foreign for conventional banks in the sense that money today is deemed better than money tomorrow, the concept is taken much more to heart in its Shariah interpretation. As was noted in the text above, Muslims are expected to shun interest (riba). By prohibiting the obtaining of interest on money lent (or the paying interest on money borrowed) Shariah law underlines the time-value of money ${ }^{32}$ as value attached to the present time. In this reading of Shariah, whatever value money can accumulate over time, should be unnecessary, not valuable and unacceptable.

However, reality suggests that the practical approach of Shariah practitioners to this issue is slightly more flexible. It appears that in the course of an investment the time-value of money may be estimated not at the beginning but at the end, when the outcome of the transaction has become known. ${ }^{33}$ The relevance of this is that a flexible attitude to how money is treated may open the doors to money being used in novel ways while remaining compliant with Shariah. As will be seen further below, this may have been partially why FinTech-enabled P2P lending has been seen as acceptable in the Islamic finance environment.

The above should have helped to clarify that lending of money, which is one of the main activities of conventional retail banks, operates in a fundamentally different way when done in a Shariah-compliant setting. Typically, in a lending-of-money scenario, a conventional bank will act as a money lender, gaining its profit through the interest attached to the loan, and the relationship (in this context) between banks and clients is one of a debtor/creditor. The Islamic alternative to this are trade or equity-based Shariah-compliant transactions. ${ }^{34}$ Put more simply, under Shariah, as money has no value of its own and as interest on money lent is not permitted, the Islamic bank will participate in the transaction not by securing itself against the possibility of the customer defaulting on the loan (by charging interest) but by sharing the risk and profit derived from the particular transaction. ${ }^{35}$ This is done in two main waysthrough murabaha (cost-plus financing) where the bank buys a product at a price and sells it back to you at a higher price and musharaka (forming a partnership), which is a more complicated way of co-owning of a product. In this latter case, at the beginning the bank owns the majority of the shares in an asset but it sells them to you gradually, over the course of time. In comparison, in the murabaha example, the bank owns the asset outright and the customer receives ownership only upon paying in full. In the second example, the asset is owned by the partnership.

\footnotetext{
${ }^{32}$ Khan [31].

${ }^{33}$ Kahf [29], p. 38.

${ }^{34}$ Islamic Finance Advisory Board [26].

${ }^{35}$ The Exchange [39].
} 
It is evident that the above financial vehicles serve to provide an end result, which would be consistent with Shariah law, while remaining attached to the reality of the market. What is more, it could even be suggested that the murabaha and musharaka instruments serve to 'rephrase' the Western approach in a Shariah acceptable language, while keeping the nature of the transaction the same. It is arguable, therefore, that Islamic Finance could take the same approach with respect to FinTech with a view of incorporating as many technical innovations in its framework as would be practically possible.

\section{Part Three}

\section{What is FinTech and how does it relate to conventional banking?}

A good definition of FinTech describes it as a 'portmanteau of financial technologies', characteristic of the financial services of the twenty-first century. ${ }^{36}$ What started as a back-end innovations process, supplementing the already established consumer and trade financial institutions, went on to become a fully-fledged, comprehensive frontend ecosystem, culminating in the creation of digital currencies such as bitcoins and altcoins. $^{37}$

At the time of writing, a lot of negative connotations are being attached to so-called crypto-currencies. However, FinTech goes far beyond that-both generally and more particularly so in the banking context. A good account of what the 'new normal' for banking, established by FinTechs entails, argues that it helps 'disrupt the sales of banking products by fulfilling customer expectations using agile processes and greater customer orientation, and accelerating their speed of innovation. ${ }^{38}$

In principle, there should be no reason why banks should not be open to financial innovation and why they should not try to absorb in their practices as much FinTech as would be beneficial for them. This applies to both conventional and Shariahcompliant banks.

However, incorporating all of the benefits derived from FinTech may not be so easy for either. To begin with, when considering the conventional banking context, it should be clear that the speed at which FinTech develops far exceeds that of conventional banks. More importantly, banks are subject to very strict regulation while the majority of FinTech's incarnations remain largely unregulated, at least for now. ${ }^{39}$ This is arguably one of the reasons why it would be difficult for the former to absorb (all) the potential benefits of the latter. Nevertheless, some have counter-argued that this should not necessarily be the case and that, as a matter of principle, banks and FinTech should merge well as the simplicity of most of the products used in retail banking makes them well adapted to disruption. ${ }^{40}$ How this is expected to play out in practice is seen by the following prognosis:

\footnotetext{
${ }^{36}$ Investopedia [20].

${ }^{37}$ Investopedia [20].

${ }^{38}$ Drummer et al. [10], p. 2.

${ }^{39}$ Drummer et al. [10], p. 2.

${ }^{40} \mathrm{PwC}$ [37].
} 
- over $90 \%$ of banks expect growth in the usage of mobile applications, much higher than any other financial sector.

- fast-paced user increase is also expected in usage of website and/or web-based platforms $(82 \%)$.

- traditional providers are increasingly taking a 'mobile-first' approach to reach out to consumers, e.g., designing their products and services with the aim of enhancing customer engagement via mobile.

- More than half (52\%) of the respondents in our survey offer a mobile application to their clients, and $18 \%$ are currently developing one. ${ }^{41}$

It is suggested, however, that the FinTech inclusion hinted to above would do little more than scratch the surface of the numerous possibilities derived from FinTech and explored by FinTechs. In the particular case of retail banks, their focus should be on how best to utilise their relationship with customers so that they can maximise financial gains for the bank (while staying within the frame of banking regulation). In a post-FinTech era this is easier said than done as banks experience fierce competition from FinTech-enabled third parties, attracting their former customers in large numbers. This tendency is facilitated further by regulation such as the Payment Services Directive II ${ }^{42}$ which provides bank customers with the opportunity 'to use third-party providers to manage their finances' ${ }^{43}$ More importantly though, this trend is facilitated by the very nature of FinTechs-innovation-based, lightly-regulated start-ups, always on the lookout for opportunities to attract new business, including business that traditionally has been the domain of the banks. To this end, the following quote seems relevant:

"[FinTechs] disintermediate client relationships from banks by providing aggregator services, putting banks in the position of pure providers of infrastructure and commodity products in extreme cases. As well as offering old products in a new guise, FinTechs develop completely new services, such as cross-border peer-to-peer $(P 2 P)$ payments, micro-lending or robo-investment platforms where almost all processes are based on algorithms, and barely any human intervention is required. This makes some established offerings obsolete, and diminishes the profit pools of banks." 44

Just two examples from Germany, Auxmoney and Number26, provide proof that FinTechs can be real competitors to conventional banks. Auxmoney provides lending services leveraging Big Data to obtain credit ratings of its potential customers ${ }^{45}$ and Number26 allows a bank account to be opened and managed via the customer's smart phone. ${ }^{46}$ It should be noted that, given the relative lack of sophistication of FinTechs,

\footnotetext{
${ }^{41} P w C$ [37].

${ }^{42}$ Directive 2015/2366/EU of the European Parliament and of the Council of 25 November 2015 on payment services in the internal market, amending Directives 2002/65/EC, 2009/110/EC and 2013/36/EU and Regulation (EU) No 1093/2010, and repealing Directive 2007/64/EC [2015] OJ L 337/35.

${ }^{43}$ Evry [12].

${ }^{44}$ Drummer et al. [10], p. 2.

${ }^{45}$ Auxmoney [3].

${ }^{46} N 26[36]$.
} 
the benefits discussed above, can mostly be reaped by retail bank customers rather than corporate/investment banking customers. Banks can (for now) still rely on the business provided by their corporate clients. However, in terms of retail bank customers, the danger presented by FinTechs to banks is a very serious one. This is due to FinTechs having their focus predominantly on consumer satisfaction and innovation, while keeping their overheads to a minimum. This combination leads not only to FinTechs being able to provide their consumers with arguably better and cutting-edge banking services but an ability to do so at a significantly reduced price which consequently reduces the fees paid by consumers. A good example of the above is a UK P2P money transfer service provider, the fees of which are substantially lower than those that would normally be paid if the same service were provided by a bank. ${ }^{47}$ The foregoing analysis lends itself to the conclusion that although FinTech presents a danger to the highly sophisticated conventional banking market, its ability to reach to customers and to do so at a much lower price should be utilised by Islamic banking professionals to their benefit.

\section{Part Four}

\section{Elements of FinTech that have already been implemented in Shariah-compliant finance}

\section{Overview}

This paper has so far argued that Islamic finance is based in tradition and strongly connected to the prescriptions and proscriptions contained in Shariah law. Such a reading of Islamic finance is generally uncontested among theorists. Despite that however, and even before FinTech had become ubiquitous, Islamic finance has been touted to offer 'innovative financial solutions to an under-served market' ${ }^{48}$ Admittedly, the solutions referred to were by no means FinTech solutions; still, this aspect of Shariah is pertinent to how quickly Islamic law can absorb innovations.

Having said this, due to its relatively young age and its strong religious underpinning, Islamic finance displays a number of features which do not sit comfortably with the typical Western investor (and perhaps, also with that part of the Muslim population which choose to bank in the conventional way). While the purpose of this paper is not to discuss these features in detail, it should be mentioned, for instance, that the lack of a wide choice in Shariah-compliant investment instruments can be a particular issue, something even more the case if we consider short-term investment instruments. In addition, Shariah banks are quite rigid in that they are typically not in favour of giving out personal loans. It appears that they are also reluctant to give loans to business:

"Despite the fact that 76 percent of enterprises in MENA has a bank account, only 26 percent reported having a credit from a financial institution. Given

\footnotetext{
${ }^{47}$ Finder [14].

${ }^{48}$ Khaleej Times [30].
} 
this low credit penetration at the corporate level in Muslim countries, some solutions have been implemented to narrow the credit gap which is estimated to be more than US\$140 billion." 49

Instead of giving personal loans, Islamic banks prefer to directly invest in the desired asset or venture through the Shariah-specific musharakah and mudarabah products (as discussed above). ${ }^{50}$ Although this practice has its benefits, it can also diminish the possibilities open to their customers.

Furthermore, these practices can harm the banks themselves. Since Islamic banks do not offer interest on deposits, they lag behind their conventional counterparts in terms of the amount of money deposited with them. Last (but certainly not least), Islamic banks are more liquid. They like to 'play it safe' by securing an equity/debt ratio in favour of equity, to an extent greater than that typically seen in conventional banks. ${ }^{51}$ This creates security but also stagnation (and contradiction) as banks having excess liquidity appear to struggle with investing in the short-term while at the same time expecting quick returns on lending. ${ }^{52}$ On the other hand, the expectation of quick returns on lending dissuades banks from funding projects, specifically long-term ones. Such attitudes arguably contradict one of the principles of Shariah, namely, to preserve resources and nurture wealth created by labour and effort (as opposed to by risk and speculation).

Furthermore, the issue of the wide credit gap is one of the challenges which Islamic finance has had to deal with in the past and even more so in the present. One consequence of this issue is having a huge part of the overall Muslim population unrepresented in the context of financial services. Not only is this discriminatory, unfair and against the principles of Shariah (which strive to achieve fairness, social inclusion and balanced distribution of wealth in society), but it is also short-sighted with respect to efficiently developing the Shariah-based system of financial services. Furthermore, missing out on FinTech may mean losing the under-30s demography in Muslim countries. Considering that the majority of this tech-savvy generation owns a smart phone, it would be hard to imagine that they will not make use of the possibility to manage their financial needs, including paying bills, obtaining loans or even opening a bank account, digitally. And if that means digitally crossing the border, inadvertently placing themselves outside the remit of Shariah, then this is what will perhaps happen.

In addition, when they do decide to fund a project or to lend money, Islamic banks are known to charge higher rates compared to conventional banks. Quite apart from losing the younger generation, Shariah-compliant banks tend to lose potential 'good' debtors (debtors who have banked with the institution in the past and are in a position to return their loans on time) who chose to obtain loans from conventional credit institutions. Instead and to compensate for the loss of business, Islamic banks seem to attract a number of 'bad' debtors (debtors who will default on their loans), thus

\footnotetext{
${ }^{49}$ de Luna-Martinez/Campillo Diaz [9].

${ }^{50}$ Khaleej Times [30]; de Luna-Martinez/Campillo Diaz [9].

${ }^{51}$ Iqbal [23], p. 57. See also, Muhammad/Manarvi [35], p. 7; Loghod [33].

${ }^{52}$ Iqbal [23].
} 
bringing the rate of non-performing loans to a high level. ${ }^{53}$ It has also been suggested that Islamic banks suffer from excessively high overheads which, combined with the non-performing loans issue, drives up the price of their lending. ${ }^{54}$

While the above analysis is by no means exhaustive, it certainly leads to the conclusion that one significant consequence of the Islamic banking practices, as they now are, is the increase of the price of banking in the Shariah banking framework. To this end, it is suggested that by incorporating FinTech-based solutions (which evidently provide for faster, consumer-oriented and cheaper transactions), Shariah banks could create investment products that are both Shariah-compliant and cheaper. ${ }^{55}$

Furthermore and more generally, by adopting FinTech, Shariah finance can remain current for its younger users, many of whom, due to the specific nature of FinTech, have already been exposed to the FinTech-related developments and investment possibilities in the West.

Interestingly, it appears that Western FinTechs themselves would have interest to penetrate the Islamic financial market and to tap on its potential. More specifically, this applies to FinTechs working with blockchain technology. For example, the Canadian firm Goldmoney Inc. claims that its products, which are backed by gold, are Shariah-compliant according to the guidance issued in the Accounting and Auditing Organization for Islamic Financial Institutions. 56

It makes sense, therefore, to try and identify those FinTech instruments that could be adopted by Islamic finance professionals. Although most FinTech instruments are flexible enough to adapt to the needs of the Shariah market, it has been suggested that some of the most suitable among them are P2P lending and Robo advice. ${ }^{57}$ Due to length restrictions, this paper will only consider the implications of the former.

\section{P2P lending in Shariah-compliant finance}

P2P lending (also known as crowdlending or social lending) is a non-intermediary way of debt financing, through which individuals can borrow and lend money between themselves. While cheaper, P2P is said to be riskier, and more time- and effortconsuming than lending or borrowing done through a traditional credit institution. ${ }^{58}$

$\mathrm{P} 2 \mathrm{P}$ elements that have been introduced to Islamic finance include P2P crowd funding, remittance and mobile wallet.

Crowd funding In principle, crowd funding connects a borrower and a creditor without the need for the two to live in the same country or even to know each other. This arguably makes it suitable to the Shariah context. Furthermore, there are some Shariah-compliant products that seem suitable for crowd funding. Among them are murabaha (mark up) for buying an asset and the musharakah-or mudharabah-based

\footnotetext{
${ }^{53}$ Beik/Arsyianti [6].

${ }^{54}$ Beik/Arsyianti [6].

${ }^{55}$ Kocianski [32].

${ }^{56}$ Vizcaino [43].

${ }^{57}$ Vizcaino [43].

${ }^{58}$ Investopedia [22].
} 
equity financing model. Using FinTech (as well as other digital innovations, such as social media) for such transactions seems intuitive, as it leads to lowering of transaction costs. As P2P lending is based on risk-sharing (vs. risk-transferring), it is Shariah-compliant. ${ }^{59}$

Remittance FinTech-enabled remittance makes movement of money much cheaper, something that is of interest to the many migrants needing to send money to their families in their home countries. Importantly, remittance can be done even without having a bank account. Instead of moving money cross-border, FinTech connects senders cross-border re-routing money domestically.

Mobile wallet The mobile wallet feature gives the beneficiary the opportunity to pay their utility bills and perform other micropayments by using only their smart phones. This enables users without a bank account (again including migrants) to participate actively in day-to-day life and to benefit from services and products that would remain out of their reach otherwise. ${ }^{60}$

It is suggested that these features of $\mathrm{P} 2 \mathrm{P}$ lending promote greater inclusion in the life of a host society for marginalised groups of people and in that, it is potentially beneficial not only for Muslim countries but also for Western countries dealing with Muslim migrants. The beneficial aspects of P2P lending seem to have been appreciated by Muslim entrepreneurs. Demonstrating the extent to which Shariah and FinTech are compatible (and that FinTech attracts all sorts of entrepreneurs), the founder of one of the most famous mobile payments platforms in Indonesia is also a famous Islamic cleric. As of June 2017, Yusuf Mansur, co-founder of Paytren has applied for his start-up to become Indonesia's 'first Shariah-compliant, mobile, P2P lender'. ${ }^{61}$

With the help of entrepreneurs such as Mansur, it is hoped that P2P lending will become part of Indonesia's financial landscape. It is expected to meet some of the $\$ 70$ billion credit gap in the country for small- and medium-sized enterprises. ${ }^{62}$ Furthermore, the role played by $\mathrm{P} 2 \mathrm{P}$ lending is set to increase given the fact that more than half of the population of Indonesia is under 30 years old. ${ }^{63}$ To this end, another Indonesian platform that deserves interest is Investtree, which offers Shariah-compliant contracts, including P2P lending, with price and access resembling those in conventional enterprises. ${ }^{64}$

In addition to having the Middle-East open to FinTech, a number of blockchain using platforms have recently started operating in Malaysia. One of them is the Malaysian company HelloGold, which has launched a Malaysia based Shariahcompliant online platform. HelloGold hopes to expand into the neighbouring countries by $2019 .^{65}$

\footnotetext{
${ }^{59}$ Alam/Gupta [2]

${ }^{60}$ Alam/Gupta [2].

${ }^{61}$ Cosseboom [8].

${ }^{62}$ Cosseboom [8].

${ }^{63}$ Cosseboom [8].

${ }^{64}$ Cosseboom [8].

${ }^{65}$ Cosseboom [8].
} 
When it comes to innovation and Shariah-compliant finance, Malaysia can provide another interesting example. At the beginning of 2016, an Investment Account Platform (IAP) was implemented in the country. The purpose of this platform was to bring together projects in need of funding and investors. The role of the bank is not to provide funding. Rather, the bank is there to ensure that the project complies with Shariah; particularly that it is not excessively risky. The next step of the bank is to screen the project provider and assign a credit rating to them. Upon completing this, 'the project is uploaded to a platform where the investors can select the investment according to their risk appetite.' ${ }^{66}$ Notably, the Malaysian Government has allocated \$47.8 million for start-ups under the Working Capital Guarantee Scheme (WCGS) Fund. Additionally, in their quest to create a friendlier environment for FinTech interested SMEs and start-ups, the Malaysian central bank and financial regulator Bank Negara Malaysia created a regulatory sandbox framework for FinTech projects. ${ }^{67}$

The above suggests that FinTech generates considerable interest in the Islamic financial market, amongst both market players and regulators; how far this interest will be taken, however, particularly in comparison to the West, is yet to be found out.

\section{Part Five}

\section{Conclusions}

By way of introduction to this section, it should be noted that the first decade of the 21 st century witnessed a significant increase in Islamic banking's presence in the world's financial markets. While the economic stagnation after the crisis has somewhat tamed this upward tendency, Islamic finance continues manifesting resilience in the face of its competition from the conventional financial market. Its attractiveness to the billions of Muslims around the world has not diminished and its general ability to withstand adverse financial market scenarios has made it somewhat more appealing than it has ever been to the Western banking market. Additionally, it has been noted that the number of non-Muslim customers has increased in the last years. ${ }^{68}$

This said, Islamic finance lags behind in total number of customers and degree of sophistication of the products available in its portfolio. Technology is something which is credited with having a positive effect on banking, Islamic banking included. In the example of the latter, technology could be relied upon to achieve greater alignment with conventional financial instruments and products, more specifically those that are deemed compliant or at least compatible with the Islamic religious code. Such alignment will arguably be in the best interest of Islamic banks as it will increase their general competitiveness. Furthermore, technology can bring about greater transparency, which would enable all stakeholders (bankers, Islamic courts, customers) to scrutinise the transactions that take place in a Shariah finance/Shariah banking environment.

\footnotetext{
${ }^{66}$ de Luna-Martinez/Campillo Diaz [9].

${ }^{67}$ Alam/Gupta [2].

${ }^{68}$ Islamic Banker [25].
} 
The analysis of Shariah-compliant P2P lending suggests that aspects of it such as crowd funding, remittance and mobile wallet are particularly appropriate for the needs of a big part of the population in Islamic countries. It gives those who are left out of the possibility to bank with a traditional credit institution the ability to engage in financial transactions, pay their bills or send money abroad, to name just a few. Furthermore, P2P lending may help close or narrow the huge credit gap existing in Muslim countries, preserve more of the local money within the local financial market and allow local banks to generate more profit at a price, which will be lower for all stakeholders.

Although this article focused only on P2P lending in the Shariah context, it should not be concluded that this is the single FinTech enabled product suitable for users wishing to bank in line with Shariah law. FinTech could potentially give a number of opportunities to banking practitioners and customers that go outside the sphere of P2P. For example, technology can offer readily available standardised contracts (helping alleviate the risks attached to some products). Furthermore, digitalising banking services could bring savings for banks and their customers in terms of time, effort and money. Additionally, apart from lowering overheads, technology can be utilised in a way which helps reduce transactional risks, for example by using blockchain. Last but not least, the neutrality of FinTech is one of its attractive aspects as making of Islamic finance framework more current for its users can be carried out without leaving it open to accusations of blindly copying the Western system. Furthermore, financial technologies can be applied and utilised with the same success in conventional and Shariah - compliant settings. To this end, Islamic finance practitioners are at liberty to choose which FinTech elements to incorporate or develop in their practice in order to increase their efficiency and inclusion while remaining true to the values of Islam.

\section{References}

1. Abou El Fadl, K.: The nature of law and morality (2018). https://www.plainislam.com/in-depth/thenature-of-law-and-morality/

2. Alam, N., Gupta, L.: How FinTech Can Tap into Islamic Finance (2017). https://journal.wahedinvest. com/how-fintech-can-tap-into-islamic-finance/ (accessed 24 December 2017)

3. Auxmoney: So leiht man Geld heute (2018). https://www.auxmoney.com/ (accessed 5 January 2018)

4. Islam, B.: Broad Distinction Between Islamic \& Conventional Banking (2010). http://bankislam.com. my/en/Documents/shariah/BroadDistinctionBetweenIslamicConventional.pdf (accessed 29 January 2018)

5. Beattie, A.: The Evolution of Banking (2018). https://www.investopedia.com/articles/07/banking.asp (accessed 30 January 2018)

6. Beik, I.S., Arsyianti, L.D.: Why The Rate Of Financing In Islamic Banks Is High? An Analysis Based On Malaysian Case (2008). https://www.researchgate.net/publication/280723213_Why_The_Rate_ Of_Financing_In_Islamic_Banks_Is_High_An_Analysis_Based_On_Malaysian_Case (accessed 29 January 2018)

7. Berger, M.: Sharia—a flexible notion. R\&R 3, 335 (2006). https:/www.clingendael.org/sites/default/ files/pdfs/20060000_cdsp_art_berger.pdf (accessed 30 January 2018)

8. Cosseboom, L.: Shariah-compliant P2P lending is the 'Wild West' in Indonesia (2017). https:// www.salaamgateway.com/en/story/shariahcompliant_p2p_lending_is_the_wild_west_in_indonesiaSALAAM01082017053423/ (accessed 5 January 2018)

9. de Luna-Martinez, J., Campillo Diaz, S.: Islamic finance in Malaysia: Filling the gaps in financial inclusion (2018). http://blogs.worldbank.org/eastasiapacific/islamic-finance-malaysia-filling-gapsfinancial-inclusion (accessed 24 January 2018) 
10. Drummer, Jerenz A, D., Siebelt, P., Thaten, M.: FinTech-Challenges and Opportunities How digitization is transforming the financial sector (2016). https://www.mckinsey.de/files/160525_fintech_ english.pdf (accessed 28 January 2017)

11. Encyclopaedia Britannica: Arabia Since The 7th Century (2018). https://www.britannica.com/topic/ history-of-Arabia/Arabia-since-the-7th-century (accessed 20 January 2018)

12. Evry: PSD2 - the directive that will change banking as we know it (2017). https://www.evry.com/en/ news/articles/psd2-the-directive-that-will-change-banking-as-we-know-it/ (accessed 18 November 2017)

13. Feridon, H.: The flexibility of Shariah (Islamic law) with reference to the Iranian experience. Glasgow Caledonian University (1998)

14. Finder: Cut out the middle man with peer-to-peer money transfers (2017). https://www.finder.com/ international-money-transfers/peer-to-peer (accessed 28 January 2018)

15. Haltom, R.: Islamic Banking, American Regulation. Econ focus (2014). https://www.richmondfed. org/ /media/richmondfedorg/publications/research/econ_focus/2014/q2/pdf/feature1.pdf (accessed 3 January 2018)

16. World, H.: History of Banking (N.d.). http://www.historyworld.net/wrldhis/PlainTextHistories.asp? historyid=ac19 (accessed 15 December 2017)

17. Injadat, E.M.M.: Futures and forwards contracts from perspective of Islamic law. J. Econ. Polit. Econ. 1(2), 241-252 (2014)

18. Institute of Islamic Banking and Insurance: Shari'ah Rulings and Finance (N.d.). http://www.islamicbanking.com/shariah-rulings-finance.aspx (accessed 5 January 2018)

19. Investment \& Finance: Islamic Finance (2017). http://www.investment-and-finance.net/islamicfinance/questions/what-is-the-difference-between-qimar-and-maysir.html (accessed 5 January 2018)

20. Investopedia: FinTech (2017). https://www.investopedia.com/terms/f/fintech.asp (accessed 25 January 2018)

21. Investopedia: Gharar (2017). https://www.investopedia.com/terms/g/gharar.asp (accessed 5 January 2018)

22. Investopedia: Peer-To-Peer Lending (P2P) (2018). https://www.investopedia.com/terms/r/retail_ lender.asp (accessed 5 January 2018)

23. Iqbal, A.: Liquidity risk management: a comparative study between conventional and Islamic banks of Pakistan. Glob. Bus. Manag. Res. Int. J. 12(5), 57 (2012)

24. Islamic Banker: An Early Experiment: Islamic Banking (2018). https://islamicbanker.com/education/ early-experiment-islamic-banking (accessed 5 January 2018)

25. Banker, I.: FinTech For Islamic banking Reporting Faces Standardization Challenges (2017). https:// www.islamicbanker.co/2017/09/01/fintech-for-islamic-banking-reporting-faces-standardizationchallenges/ (accessed 28 January 2018)

26. Islamic Finance Advisory Board: Permission \& Prohibition under Islamic Law (2016). http:// islamicfinanceboard.com/permission-prohibition-islamic-law/ (accessed 27 December 2017)

27. Islamic Finance Advisory Board: The Purpose of Islamic Law (2016). http://islamicfinanceboard. com/the-purpose-of-law-2/ (accessed 26 December 2017)

28. Jamaldeen, F.: Seven Prohibited Industries in Islamic Financial Investments (2017). http://www. dummies.com/personal-finance/islamic-finance/seven-prohibited-industries-in-islamic-financialinvestments/ (accessed 5 January 2018)

29. Kahf, M.: Time value of money and discounting in Islamic perspective: re-visited. Rev. Islam. Econ. 3(2), 31-38 (1994)

30. Times, K.: Challenges facing Islamic financial institutions (2005). https://www.khaleejtimes.com/ article/20050805/ARTICLE/308059992/1036 (accessed 24 January 2018)

31. Khan, M.F.: Time value of money and discounting in Islamic perspective. Rev. Islam. Econ. 1(2), 35-45 (1991)

32. Kocianski, S.: Islamic Finance Report (2016). http://www.businessinsider.de/the-islamic-financereport-2016-11?r=US\&IR=T (accessed 24 January 2018)

33. Loghod, H.A., Do: Islamic banks perform Better than Conventional banks: Evidence from Gulf Council Countries. API-Working Paper Series, Arab Planning Institute-Kuwait, Information Center (2006)

34. McKeefery, J.: Seventh Century: The Rise of Islam (N.d.). http://www.secthoughts.com/ John's\%20Papers/07th\%20century.pdf (accessed 30 January 2018)

35. Muhammad, J., Manarvi, I.: Performance compariosn of Islamic and conventional banks in Pakistan. Glob. J. Manag. Bus. Res. 11(1), 7 (2011) 
36. N26: A bank account with features built for real people (2018). https://next.n26.com/en-de/bankaccount (accessed 05 January 2018)

37. PwC: Consumer banking braces for disruption (2017). https://www.pwc.com/gx/en/industries/ financial-services/publications/fintech-is-reshaping-banking.html (accessed 15 December 2017)

38. Thai Bank Museum: How Banking Began (2010). http://www.thaibankmuseum.or.th/eng/ museum202.php (accessed 05 December 2017)

39. The Exchange: Sharia Law for Loans and Mortgages in the UAE (2014). http://blog.holbornassets. com/?p=843 (accessed 29 January 2018)

40. Understanding Islam: The Four Schools of Law in Islam (N.d.). http://free-islamic-course.org/ stageone/stageone-module-4/four-schools-law-islam.html (accessed 5 January 2018)

41. University of Pennsylvania: A Concise Summary of the Evolution of Islamic Law (Sharia) From its Inception to the Present (N.d.). http://www.upenn.edu/emeritus/IslamicLaw.pdf (accessed 5 January 2018)

42. Visser, H.: Islamic Finance: Principles and Practice, 2nd edn. Edward Elgar, Cheltenham Glos (2013)

43. Vizcaino, B.: FinTech platforms add Islamic finance capabilities (2017). https://www.reuters.com/ article/us-islamic-finance-fintech/fintech-platforms-add-islamic-finance-capabilitiesidUSKBN1580DO (accessed 24 January 2018) 